\title{
Immunomagnetic separation of cells of the toxic dinoflagellate Alexandrium fundyense from natural plankton samples
}

\author{
Angeles Aguilera, Sonsoles Gonzalez-Gil, Bruce A. Keafer, Donald M. Anderson*
}

Biology Department, Woods Hole Oceanographic Institution, Woods Hole, Massachusetts 02543, USA

\begin{abstract}
A novel method was developed for isolating cells of the toxic dinoflagellate Alexandrium fundyense from preserved natural seawater samples using paramagnetic beads and a monoclonal antibody against the surface antigens of the dinoflagellate. 'Direct' and 'indirect' approaches to bead/cell attachment were tested as well as 3 types of bead coatings (streptavidin, and 2 secondary antibodies: sheep anti-mouse, and goat anti-mouse), and 2 blocking agents [normal goat serum (NGS) and bovine serum albumin (BSA)]. Optimal 'indirect' bead attachment protocols, where the species-specific primary antibody is first bound to the target cells before bead attachment, utilized either $2.8 \mu \mathrm{m}$ streptavidin-coated beads with NGS blocking or sheep anti-mouse-coated beads with BSA blocking Although there were undoubtably some cell losses during the initial antibody-labeling and washing procedures, ca $90 \%$ of the labeled $A$. fundyense cells in unialgal cultures were removed using these bead procedures. Non-specific binding was low, as only 5 to $10 \%$ of the $A$. fundyense cells were recovered when the primary antibody was omitted. The 'direct' approach, where the species-specific primary antibody is first bound to the beads, was most effective ( $80 \%$ recovery) using sheep anti-mousecoated beads $(2.8 \mu \mathrm{m})$ with BSA blocking, and the non-specifjc binding remained very low $(<2 \%)$. When tested in 3 natural preserved plankton samples, recovery of Alexandrium spp. was ca $90 \%$ (negative controls $<10 \%$ ) using the 'indirect' method, with $5 \%$ contamination by other species. The 'direct' technique was slightly less effective on the natural samples (ca $80 \%$ recovery), but negative controls were very low at $1 \%$ or less. Contamination by other species was 5 to $10 \%$. 'Direct' attachment is a simpler procedure than the 'indirect' approach because the beads can be pre-coated with the specific antibody in bulk before use. Thus, the direct method not only shortens the procedure by eliminating the need to antibody-label each individual sample but, as a consequence, minimizes target cell losses as well, so it may be the method of choice for working with field samples. Immunomagnetic separation of a single algal species from a sample containing mixed plankton and detritus is thus simple, rapid, and quite reliable. Compared with other sorting methods currently in use (e.g. manual pipette isolation, flow cytometry), this procedure offers distinct advantages with respect to cost, volume, speed and simplicity.
\end{abstract}

KEY WORDS: Cell sorting - Dinoflagellate - Dynabeads - Red tides - Immunomagnetic isolation Immunofluorescence - Magnetic beads - Alexandrium fundyense

\section{INTRODUCTION}

There are many situations in phytoplankton ecology when the physiology, growth, or bloom dynamics of one particular species is of interest. Examples abound

\footnotetext{
- Addressee for correspondence.

E-mail: danderson@whoi.edu
}

in the study of red tides or harmful algal blooms, where the abundance or behavior of one phytoplankton species can have major public health, ecosystem, or economic impacts. These impacts often occur when the harmful species (e.g. Alexandrium fundyense) is only a minor fraction of the plankton community biomass (Yasumoto et al. 1980, Franks \& Anderson 1992). In such cases, standard techniques for measurements of parameters such as chlorophyll, primary production, or 
nutrient uptake are not useful since they typically provide data for entire planktonic communities rather than individual species. Methods have been developed that provide measurements of species-specific primary production and photosynthetic activity (Rivkin \& Seliger 1981, Rivkin 1985), but manual micropipette isolation of individual cells of a target species is required, severely constraining the number of cells that can be collected in a reasonable time and thus limiting applications. Alternatively, when species of interest have unique size and autofluorescence characteristics, as do the prokaryotes Synechococcus or Prochlorococcus, flow cytometry can be used to obtain autecological data (e.g. Olson et al. 1990, Li 1995). However, whenever large numbers of cells are needed for analysis or when a species cannot be discriminated from others using autofluorescence or a speciesspecific probe or 'tag', flow cytometric sorting is not a reasonable option.

Ideally, separation or isolation methods are needed that rely on recognition or labeling of a target species on the basis of unique morphological, genetic, or immunological characters. Significant progress has been achieved in this respect through the use of lectins, antibodies, and oligonucleotide probes that, respectively, bind to cell surface carbohydrates (e.g. Sharon \& Lis 1989, Costas et al. 1993), surface proteins (e.g. Campbell \& Carpenter 1987, Anderson et al. 1989, Nagasaki et al. 1989, Shapiro et al. 1989, Sako et al. 1993, Vrieling et al. 1994), and unique DNA or RNA sequences inside the cell (Scholin et al. 1994). Of these approaches, the first 2 are more readily applied to the separation of intact, whole cells because they rely on cell surface properties, and, thus far, antibodies show the most promise in this type of application. Remarkable specificity has been achieved with both polyclonal and monoclonal antibodies (PAbs and MAbs) raised against phytoplankton cells in animal hosts. Discrimination has been achieved among phytoplankton species, and even between strains or varieties of species (e.g. Campbell et al. 1983, Bates et al. 1993, Anderson 1995).

Antibody labeling procedures are now being used in conjunction with flow cytometry for automated phytoplankton species identification and enumeration (Vrieling et al. 1995), and since some flow cytometers are capable of sorting, it will soon be possible to obtain pure samples of a species of interest using such instruments. Few researchers have access to these sophisticated and expensive instruments, however, and even those who do will find that, in many cases, it takes a great deal of time to sort a sufficient number of cells for physiological or biochemical measurements. Here we report a new application of antibody labeling of phytoplankton cells that allows the rapid and efficient isola- tion of a target species from a mixed assemblage using simple and inexpensive procedures. Antibodies are used to link small beads to target cells (Fig. 1), and this bead/cell complex is then separated from other cells and detritus using a magnet.

Immunomagnetic separation is a reliable tool for the purification and characterization of a wide range of cell types, such as tumor (Wynick \& Bloom 1990, Vrenderburg et al. 1991) and lymphoid cells (Vartdal et al. 1987). This method is also used routinely for the isolation, identification and analysis of DNA or RNA sequences (Uhlen 1989) and for isolation of DNA binding proteins (Haukanes \& Kvam 1993). To facilitate these diverse applications, magnetic beads have been developed which have high stability, high uniformity, unique paramagnetic properties, low particle-particle interaction and high dispersibility (Lund et al. 1988). Beads have been formulated with hydroxyl, carboxyl and amino groups as well as other useful molecules such as streptavidin and protein $A$ or $G$, to allow attachment of antibodies of all types. The viability of certain cell types does not seem to be affected by the attachment process (Hanau \& Smith 1988), and in some cases bead detachment is possible without harming the cells (Lund et al. 1988).

Isolation of cells by antibody-coupled magnetic beads is not a new concept, but its use in phytoplankton physiology or ecology is thus far unexplored. In this study, we took the initial steps in evaluating the efficacy and specificity of different magnetic beads and protocols for the removal of previously preserved cells of the toxic dinoflagellate Alexandrium fundyense from both clonal cultures and natural seawater samples. The ultimate goal is to use these techniques for species-specific physiological measurements.

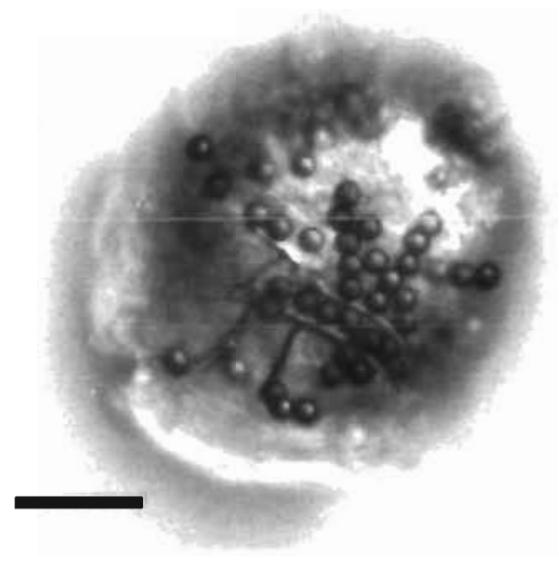

Fig. 1 Photomicrograph of Alexandrium fundyense cell with attached M-280 (2.8 $\mu \mathrm{m}$ ).) SaM beads (see 'Materials and methods'). Scale bar $=10 \mu \mathrm{m}$ 


\section{MATERIALS AND METHODS}

Cultures. Non-axenic clonal cultures of Alexandrium fundyense Balech (GTCA29), Prorocentrum micans Ehrenberg (CCMP21), Scrippsiella trochoidea (Stein) Loeblich III (SA10), and Amphidinium sp. (AMPHI) were grown in $\mathrm{f} / 2$ medium (Guillard \& Ryther 1962 ) at $20^{\circ} \mathrm{C}$ on a $14 \mathrm{~h}$ light:10 h dark cycle (ca $200 \mu \mathrm{E}$ $\mathrm{m}^{-1} \mathrm{~s}^{-2}$ irradiance, cool-white fluorescent bulbs). Cells were harvested in mid-exponential growth by centrifugation $(3000 \times g$ for $3 \mathrm{~min}$ ), preserved in formalin (5\% final conc.) and stored at $4^{\circ} \mathrm{C}$ until use. Most experiments were designed to optimize the conditions necessary for magnetic beads to bind and remove $A$. fundyense cells from unialgal cultures. One additional culture experiment attempted to isolate $A$. fundyense cells from a mixture containing 3 additional dinoflagellate species ( $P$. micans, $S$. trochoidea, and Amphidinium sp.).

Field samples. Three field samples containing Alexandrium spp. were collected in May 1993, at Boothbay Harbor, Scarborough River and New Meadows River (all in the western Gulf of Maine, USA), using a sieving technique to concentrate the relatively low abundance Alexandrium spp. population $1<200$ cells $\mathrm{l}^{-1}$ ). Seawater was successively pumped through an $80 \mu \mathrm{m}$ Nitex screen and then through a submerged $20 \mu \mathrm{m}$ screen situated immediately below. The 20 to $80 \mu \mathrm{m}$ fraction containing the Alexandrium spp. cells and other similar-sized plankton and detritus was backwashed off the $20 \mu \mathrm{m}$ screen, preserved in $5 \%$ formalin, and stored at $4{ }^{\circ} \mathrm{C}$. The 3 concentrated natural seawater samples contained ca $9 \times 10^{4}$ cells $\mathrm{ml}^{-1}$, with approximately $16 \%$ dinoflagellates (Alexandrium spp., Protoperidinium spp. and Dinophysis spp.), 40\% diatoms, and $30 \%$ other unidentified phytoplanktonic species, while detrital particles accounted for about $14 \%$ of the total. The concentrations of naturally occurring Alexandrium spp. cells (presumed to be A. fundyense or $A$. tamarense, both of which cross-react with the M-8751-1 antibody) in these concentrated samples were 150,450 , and 700 cells $\mathrm{ml}^{-1}$ respectively. In a separate experiment, $50 \mu \mathrm{l}$ of the concentrated natural samples were enriched with $1000 \pm 150$ cells from $A$. fundyense cultures. In all cases where we added cultured $A$. fundyense cells to the natural samples, cultured cells outnumbered natural Alexandrium spp. by more than 9:1.

Monoclonal antibodies. The monoclonal antibody M-8751-1 used in the development of this procedure binds to cell surface antigens of Alexandrium tamarense and $A$. catenella isolated from Japanese waters (Hiroishi et al. 1988, Adachi et al. 1993a, b). This antibody was tested for specificity against other Alexandrium strains and found to cross-react with strain CA29 (A. fundyense) isolated from the Gulf of Maine, USA (Sako et al. 1993). We also tested the antibody against natural field populations from the Gulf of Maine and found that the antibody recognized naturally occurring Alexandrium spp. from the region and did not cross-react significantly with other phytoplankton species and detritus contained in the samples examined thus far (authors' unpubl. obs.)

Preparation of magnetic particles. Several different paramagnetic beads were obtained from Dynal, Inc. (New York, USA). Initially, streptavidin-coated Dynabeads M-280 (2.8 $\mathrm{mm}$ diameter) were used to take advantage of streptavidin's high binding affinity for biotin and low non-specific binding (Wilchek \& Bayer 1988). However, the use of streptavidin-coated beads requires an additional step in the protocol, i.e. the addition of a secondary antibody that binds to the streptavidin coating already on the beads, before attachment can proceed with the target cells (i.e. GaM biotin A.b. Fig. 2). In efforts to eliminate the extra step needed to biotinylate either beads or target cells when using streptavidin, tests were also run with M-280 sheep anti-mouse $\operatorname{IgG}(\mathrm{M}-280 \mathrm{SaM})$ and the larger M-450 goat anti-mouse IgG (M-450 GaM) Dynabeads (2.8 and $4.5 \mu \mathrm{m}$ diameter, respectively).

Beads are supplied as a stock suspension containing ca 4 to $7 \times 10^{8}$ beads $\mathrm{ml}^{-1}$ in $0.02 \mathrm{M}$ phosphate buffered saline (PBS, $\mathrm{pH} 7.4$ ) containing $0.1 \%$ Bovine Serum Albumin (BSA) and $0.02 \%$ sodium azide. To remove the sodium azide before use, an aliquot of beads was removed, washed twice and then resuspended with $0.5 \mathrm{ml}$ of PBS $/ 0.1 \%$ BSA using the Dynal Magnetic Particle Concentrator (MPC-6) to collect the beads. Washed beads can be stored at $4^{\circ} \mathrm{C}$ for about 1 wk until use.

Immunomagnetic separation procedure. Following the manufacturer's suggested approach, both the 'direct' and 'indirect' methods to bead/cell attachment were tested (Fig. 2). These terms, commonly used in the magnetic bead literature, should not be confused with 'indirect' immunolabeling. Here, we refer to the primary antibody-labeling of the bead (direct) or the target cell (indirect) before attachment and not to the conjugation (or lack thereof) of a visual tag on the primary antibody. In the direct approach, a primary antibody is coupled directly to Ab-coated magnetic beads (manufactured with the Ab coating, Fig. 2A). If the bead does not have an antibody coupled to it (e.g. streptavidin-coated beads), then a secondary antibody (e.g. GaM biotin Ab) must also be bound to the bead before the primary antibody (Fig, 2A). The bead/antibody complex is then incubated with the target cells after which the bead/cell complexes are isolated using a magnet. With the indirect technique (Fig. 2B), the primary antibody is first bound to the target cells not to 
the beads. The beads, manufactured with an Ab coating (Fig. 2B) or with a streptavidim coating are then added to complete the attachment. If the streptavidincoated beads are used (Fig 2B), it is necessary to use an additional step adding a secondary antibody (GaM biotin $\mathrm{Ab}$ ) to the target cells before attachment with the beads. Again, the MPC-6 is used to magnetically remove the bead/cell complex from solution. The first 2 steps of the indirect technique are essentially the same as in current methodologies for immunofluorescent detection of algal cells (Campbell \& Carpenter 1987. Anderson et al. 1989, Nagasaki et al. 1989, Shapiro et al. 1989, Sako et al. 1993, Vrieling et al. 1994). The only difference is that the magnetic beads are used to tag the target cells for isolation, whereas the identification procedures attach a visual tag using fluorochromes such as fluorescein-isothiocyanate (FITC).
Direct technique. In the direct approach to cell attachment, it is necessary to couple antibodies to the beads before incubation with the target cells (Fig. 2A). When using the M-280 streptavidin-coated beads, prewashed beads $\left(6 \times 10^{6}\right.$ beads per $500 \mu$ sample $)$ were incubated in microcentrifuge tubes with $200 \mu \mathrm{l}$ of biotin-conjugated goat anti-mouse secondary antiserum (GaM-biotin, B-7022, Sigma Chemical Co., St. Louis, MO, USA) diluted 1:150 with PBS for $30 \mathrm{~min}$ under constant mixing at room temperature on a Labquake Shaker (LabIndustries, Inc., Berkeley, CA, USA). The MPC- 6 was used to concentrate the streptavidin/biotin bead complex, which was washed 3 times with $1 \mathrm{ml}$ of $0.1 \%$ BSA in PBS (hereafter $0.1 \%$ BSA; A6793, Sigma Chemical Co.) to remove the excess unbound biotinylated antibody. Then, $500 \mu \mathrm{l}$ of primary antibody (M-8751-1) diluted 1:50 with 5\% nor-

\section{IMMUNOMAGNETIC SORTING PROCEDURES}
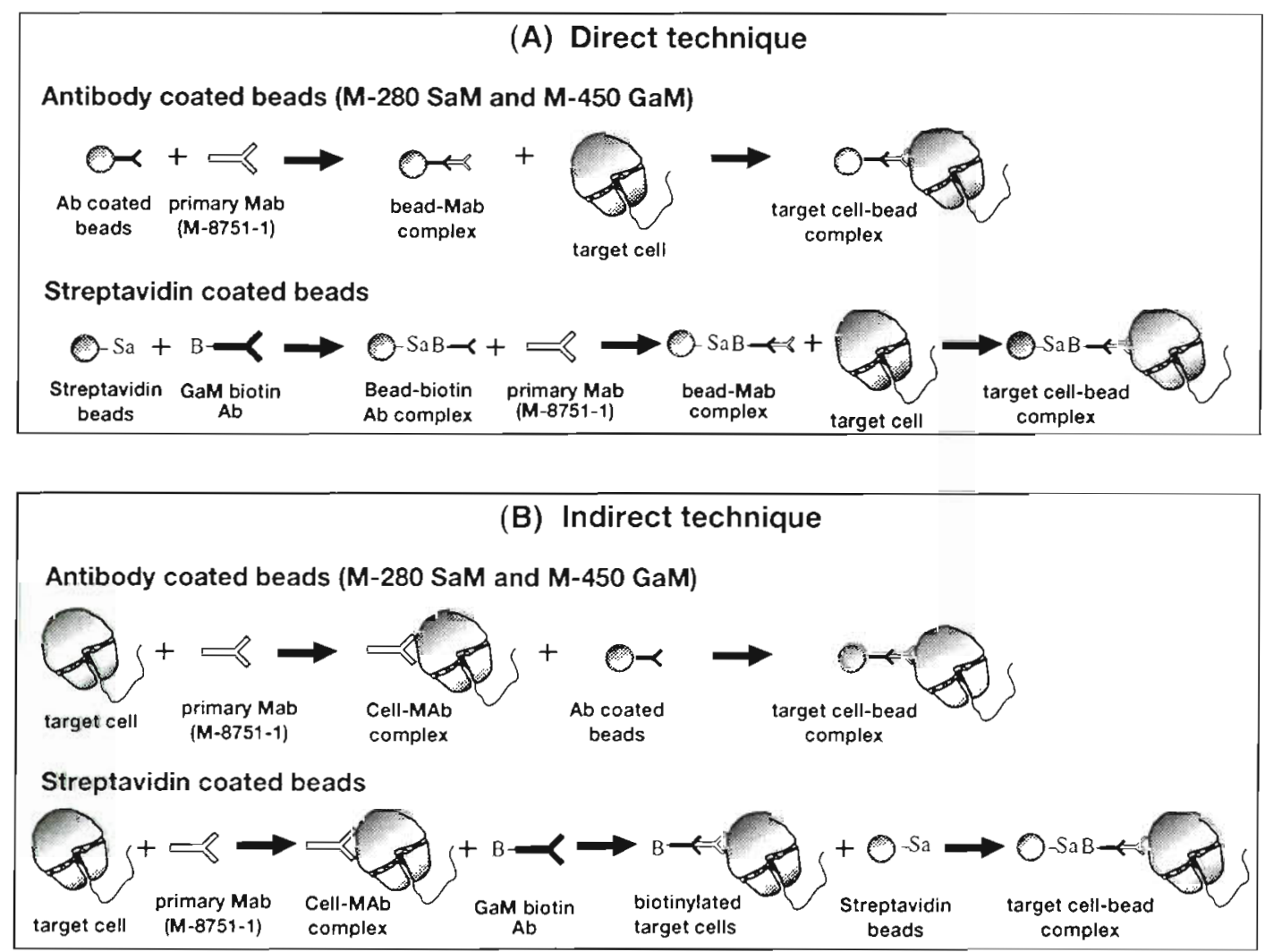

Fig. 2. Experimental approaches tested in the development of the immunomagnetic sorting procedur.. (A) Direct technique: commercially-available paramagnetic beads that were already coated with secondary antibody are uncubated with the speciesspecific primary monoclonal antibody (Mab) prior to attachment with the target cells. If streptavidin-coated beads are used, the secondary antibody (Ab), GaM-biotin, is first required before the primary Mab can be bound to the beads. After a brief incubation where 'activated' beads come into contact with the target cells, the bead/cell complexes are isolated by a magnet. (B) Indirect technique: the specific Mab is first pre-incubated with the target cells, not the beads. If streptavidin-coated beads are used, then the secondary Ab, GaM-biotin, is first required. The beads are then incubated with the antibody-coated target cells and the resulting bead/cell complexes are then isolated by a magnet 
mal goat serum (NGS, G-9023, Sigma Chemical Co.) was added, and the mixture was incubated for another 30 min on a Labquake shaker. Finally, the antibody/ bead complexes were washed 3 times with $500 \mu 10.1 \%$ BSA using the MPC- 6 and resuspended in $500 \mu 10.1 \%$ $\mathrm{BSA}$. The negative controls were incubated under the same conditions using mouse myeloma protein (MMP, M-9269, Sigma Chemical Co.) diluted 1:100 with 5\% NGS instead of the primary antibody. The protein concentration of MMP approximates the specific antibody concentration of the monoclonal antibody.

The target cells (i.e. Alexandrium spp. containing, formalin-preserved samples, either from culture or natural populations) were washed twice with $1 \mathrm{ml}$ of PBS by centrifugation $(3000 \times g$ for $3 \mathrm{~min})$ to remove the preservative, blocked with $5 \%$ NGS for $30 \mathrm{~min}$, and washed 3 times in PBS. The blocked target cells were resuspended in $500 \mu \mathrm{l}$ of $0.1 \%$ BSA and then incubated with the antibody-activated beads for 15 min with constant mixing using the Labquake shaker, which kept the beads and cells in constant suspension, with no sedimentation of either beads or cells. Before incubation, a $100 \mu$ aliquot of the sample was removed for cell counting to estimate the number of target cells present before bead attachment (see below). The target cells (i.e. Alexandrium spp.) were then separated from the medium using the MPC-6, which contains permanent magnets that attract the paramagnetic bead/target cell complexes into a pellet against the wall of the tube. After $10 \mathrm{~min}$ in the magnetic field, the supernatant was removed by aspiration. The remaining bead/target cell pellet was gently washed by resuspension in $1 \mathrm{ml}$ of $0.1 \%$ BSA and then returned to the magnetic field for another $10 \mathrm{~min}$. After 5 washes in this manner, all samples were finally resuspended in $500 \mu \mathrm{l}$ of $0.1 \% \mathrm{BSA}$, and aliquots of $100 \mu \mathrm{l}$ were removed for final counting to determine the percentage recovery of Alexandrium spp. cells (see below). BSA diluted to a final concentration of $5 \%$ in PBS was also tested as a blocking agent with the 3 types of beads analyzed. In this case, the antibodies and/or beads were incubated in 5\% BSA and all washes were with $2 \% \mathrm{BSA}$.

When using either the M-280 SaM or M-450 GaM beads instead of the streptavidin-coated beads, it was not necessary to first add the additional biotin step to the bead coating (Fig. 2). In this case, the beads were incubated for $2.5 \mathrm{~h}$ with only the primary antibody before a short $15 \mathrm{~min}$ incubation with the target cells. Bead concentrations were $6 \times 10^{6}$ and $4 \times 10^{6}$ per sample $(500 \mu l)$, respectively.

Indirect technique. Formalin-preserved samples containing Alexandrium spp. were washed as above to remove the preservative. The cell pellet was first incubated for $30 \mathrm{~min}$ with $500 \mu \mathrm{l}$ \% NGS diluted in PBS to block non-specific binding. Cells were washed 3 times with PBS, then incubated $30 \mathrm{~min}$ with $100 \mu \mathrm{l}$ of the primary antibody (M-8751-1) diluted 1:50 in 5\% NGS. After being washed 3 times with $1 \mathrm{ml}$ of PBS, the cells were biotinylated by addition of $200 \mu \mathrm{l}$ of a 1:150 dilution (with PBS) of GaM-biotin secondary antiserum to the cell pellet and incubation for 30 min. After 3 more washes in $1 \mathrm{ml}$ of $0.1 \% \mathrm{BSA}$, the biotinylated cell suspension was brought to $500 \mu \mathrm{l}$ final volume. As in the direct technique, the secondary antibody step (i.e. biotinylation) was not necessary when using the M-450 GaM beads or the M-280 SaM beads

To complete the cell isolation, an appropriate concentration (ca $6 \times 10^{6}$ beads per $500 \mu \mathrm{l}$ sample for most experiments) of the pre-washed beads was added to the antibody-labeled cells and incubated for $15 \mathrm{~min}$ under constant mixing in the Labquake shaker to insure efficient binding of the beads to the target cells The target cells (i.e. Alexandrium spp.) were then separated from the medium using an MPC- 6 as in the direct technique above. The negative controls were incubated under the same conditions using MMP diluted 1:100 with 5\% NGS instead of the primary antibody. Alternatively, $5 \%$ BSA was evaluated as a blocking agent and $2 \%$ BSA was used for the washes.

Determination of recovery percentage. After antibody labeling, but before attachment to the beads, a $100 \mu \mathrm{l}$ subsample was removed from each experimental condition or treatment. This subsample was diluted to $500 \mu \mathrm{l}$ and a minimum of 3 replicate counts of $100 \mu \mathrm{l}$ each were performed using a Palmer-Maloney counting chamber to estimate the number of cells remaining just prior to attachment. After attachment of the beads, 3 subsamples of $100 \mu \mathrm{l}$ were removed and counted as well. This estimate of cells was compared to the initial number of cells before attachment and washing of the beads to determine the percentage recovery of the algal cells. Note that this is not the same as the initial number of cells in the sample at the start of processing, as cell loss undoubtedly occurred in the washing steps prior to bead attachment. Statistical comparisons were made using the Student's $t$-test to compare means among the different treatments.

Immunofluorescent techniques were used to facilitate the counting of the Alexandrium spp. cells in natural seawater samples. The samples were first incubated with the M-8751-1 primary antibody, washed 3 times with PBS/0.1\% BSA, followed by a secondary FITCconjugated goat anti-mouse antibody (F-0257, Sigma Chemical Co., 1:100 in 0.1\% BSA) for $1 \mathrm{~h}$. If the target cells had already been exposed to the primary antibody (e.g. positive tests) during the isolation procedure, it was not necessary to add more primary antibody. All counts were enumerated under a Zeiss IM35 inverted epifluorescence microscope with an FITC filter set 


\section{RESULTS}

All experiments were performed using preserved cells since initial attempts using live cells resulted in low recoveries. Work is in progress to improve these results, but all the work reported here refers to preserved material.

\section{Bead attachment}

An example of the condition of preserved Alexandrium spp. cells after the isolation protocol using $\mathrm{M}-280 \mathrm{SaM}$ beads is depicted in Fig. 1 The number of attached beads as well as their distribution patterns around the cells was variable. Some cells had more than 100 beads covering the cell surface (most common with M-280 streptavidin beads), but it was also possible to find Alexandrium spp. cells with less than 10 beads attached, in which case the beads were usually distributed in the cingulum area and at the extremes of the epitheca and hypotheca (most common with M-280 SaM beads). The arrangement of the beads on the cells depended only on the bead type. There were no differences in the bead distribution patterns observed among the direct or indirect treatments or with different blocking agents. With the M-450 GaM beads, the cells usually had less than 10 beads attached and the distribution pattern was completely random.

For negative controls (i.e. when the Alexandrium spp. cells were incubated using MMP instead of the

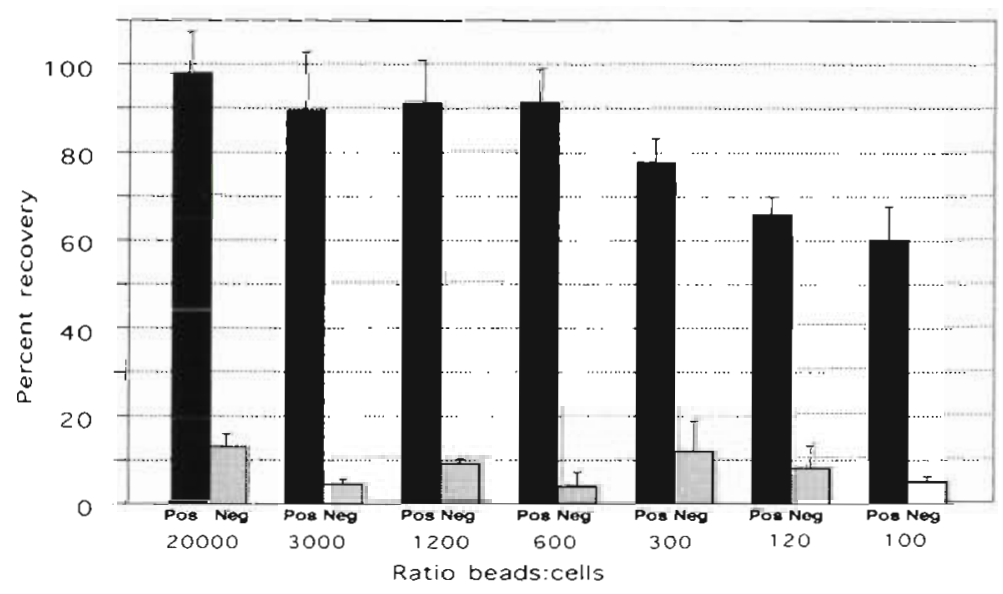

Fig. 3. Effect of the beadiarget cell ratio on the recovery of Alexandrium fundyense cells from cultures using $M-280$ streptavidin beads and the indrect technique. Samples were blocked with 5\% NGS. Pos: positive labeling with primary antibody present; Neg: negative controls with primary antibody omitted. Error bars represent +1 SD for each treatment primary antibody), the cells remaining after the isolation procedure had no attached beads. This was also true for the remaining non-Alexandrium cells in the natural seawater samples. In both cases, it would be possible to remove the unbound cells completely by increasing the number of final washes, but at the risk of losing a greater number of target cells.

In all experiments, the complexed beads remained tightly attached to the cells, while the uncomplexed beads were collected in the magnetic field along with the bead/cell complexes. The unbound beads did not present a problem for the experimental development, but might affect subsequent measurements. If necessary, unbound beads can be removed by size fractionation using gentle sieving on a nylon membrane (10 to $20 \mu \mathrm{m})$, as the bead/cell complexes are much larger than the uncomplexed beads.

\section{Optimization of target cell recovery}

Experimental conditions for the isolation of target cells from clonal cultures of Alexandrium fundyense were optimized using the M-280 streptavidin-coated beads with the indirect technique because it is generally considered a more efficient isolation technique than the direct one (Dynal, Inc.). The optimal beads:target cells ratio, the incubation time of cells with the beads, and the minimum number of final washes were all determined in light of the need to 
maximize binding efficiency while avoiding non-specific binding.

Bead:cell ratios ranging from 20000:1 to 100:1 were tested (Fig. 3). At a ratio of 600:1, $91.5 \pm$ $7.5 \%$ recovery was obtained. When the ratio was increased to $1200: 1,3000: 1$, or $20000: 1$, the recovery percentage was not significantly improved ( $p>0.05)$, as there was ca $90 \%$ removal for each treatment. When the bead:cell ratio was decreased to $300: 1$ or lower, the recovery percentage decreased to 78,66 , and $60 \%$ for ratios of $300: 1,120: 1$, and $100: 1$, respectively. Approximately $10 \%$ or less of the target cell population was recovered in the negative controls for each ratio.

When the incubation time during which the cells were exposed to the beads was varied, binding was still relatively rapid (Fig. 4). Incubations of only 5 or 10 min were able to recover 75 and $71 \%$ of the cells, respectively. The optimal incubation time was 15 min, with $91 \%$ recovery. Longer incubation times ( 30 and $60 \mathrm{~min}$ ) did not significantly increase the recovery percentage ( $\mathrm{p}>0.05$ ). A $15 \mathrm{~min}$ incubation time was thus used in all subsequent experiments. Again, the recovery percentages in the negative controls were less than $10 \%$ for all incubation times.

The number of final washes needed to remove unbound cells was evaluated as well. In the first 2 washes, nearly $80 \%$ of the unbound cells were eliminated (data not shown), while in the next 2 additional washes, more than the $10 \%$ of the remaining unbound cells were eliminated. Subsequent washings only removed an additional $1 \%$ of the unbound cells each time. Therefore, 5 washes were used for the remainder of the experiments.

\section{Direct versus indirect technique}

The 2 experimental approaches diagrammed in Fig. 2 were examined with 3 types of beads (M-280 streptavidin, M-280 SaM and M-450 GaM) and with 2 blocking reagents (NGS and BSA). With the direct technique and $M-280$ beads coated with streptavidin, only $47 \%$ of the target cells were recovered using $5 \%$ NGS as a blocking agent (Fig. 5A). When 5\% BSA was used for blocking, the percentage of recovered cells in the positive samples increased to $61 \%$. With the indirect technique and $5 \%$ NGS, the percentage increased to $92 \%$. With both the direct and indirect techniques, the recovery in the negative controls was ca $10 \%$ (12 and $8 \%$, respectively). There was no sig-
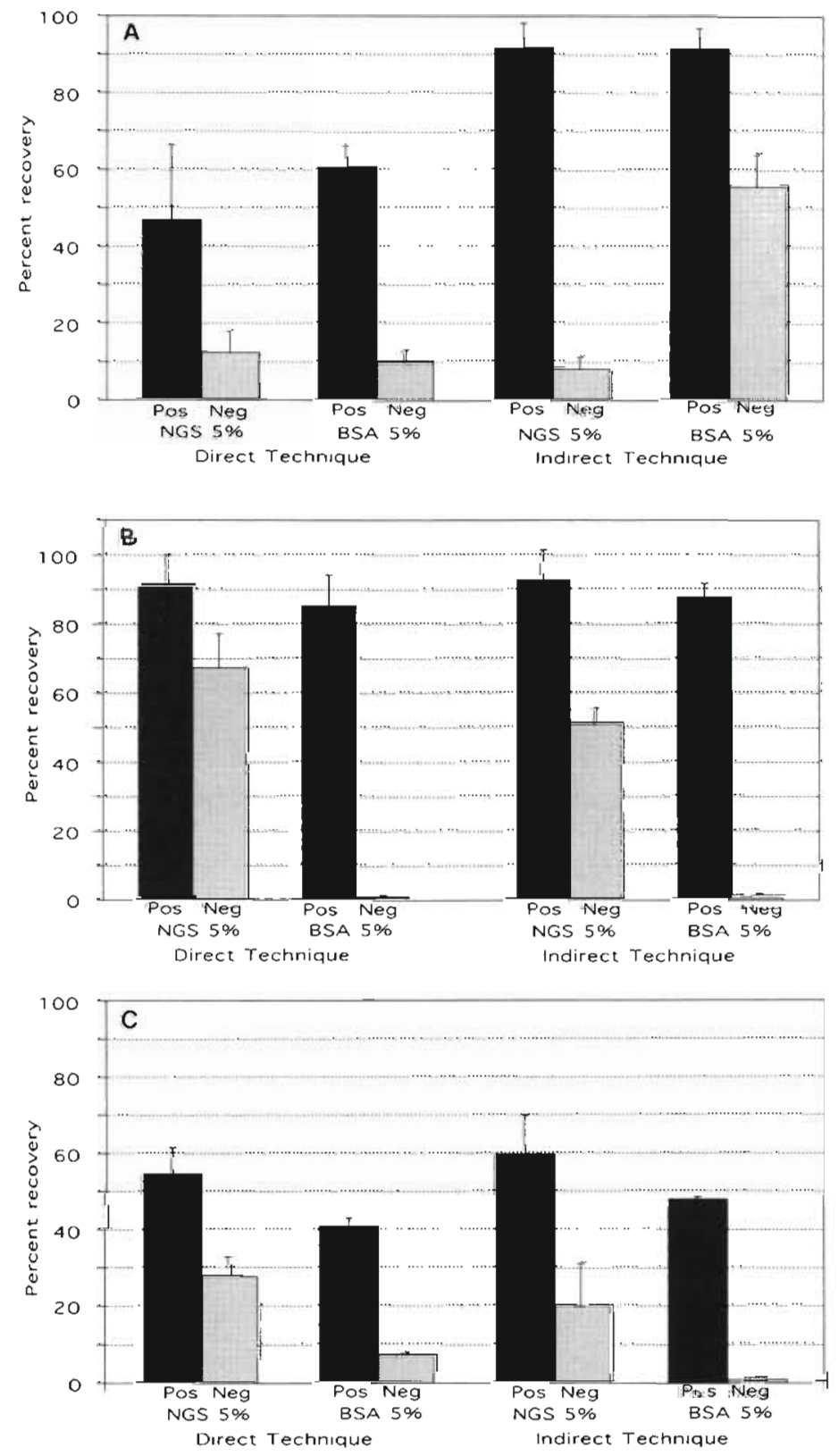

Fig. 5. Variation in percent recovery of cultured Alexandrium fundyense cells with different bead coatings and labeling approaches. (A) M-280 streptavidin-coated beads, direct and indirect techniques, and 5\% NGS and 5\% BSA for blocking. (B) M-280 SaM beads, direct and indrect techniques, and $5 \%$ NGS and $5 \%$ BSA for blocking. (C) M-450 GaM beads, direct and indirect techniques, and $5 \%$ NGS and $5 \%$ BSA for blocking. Pos: positive labeling with primary antibody present; Neg: negative controls with primary antibody omitted. Error bars represent $+1 \mathrm{SD}$ for each treatment

nificant difference $(\mathrm{p}>0.05)$ between the 2 blocking systems ( $5 \%$ NGS and 5\% BSA) for the indirect technique (92 and $91 \%$ recovery, respectively) In the negative controls, however, the recovery with the indirect technique was $56 \%$ with $5 \%$ BSA blocking compared 


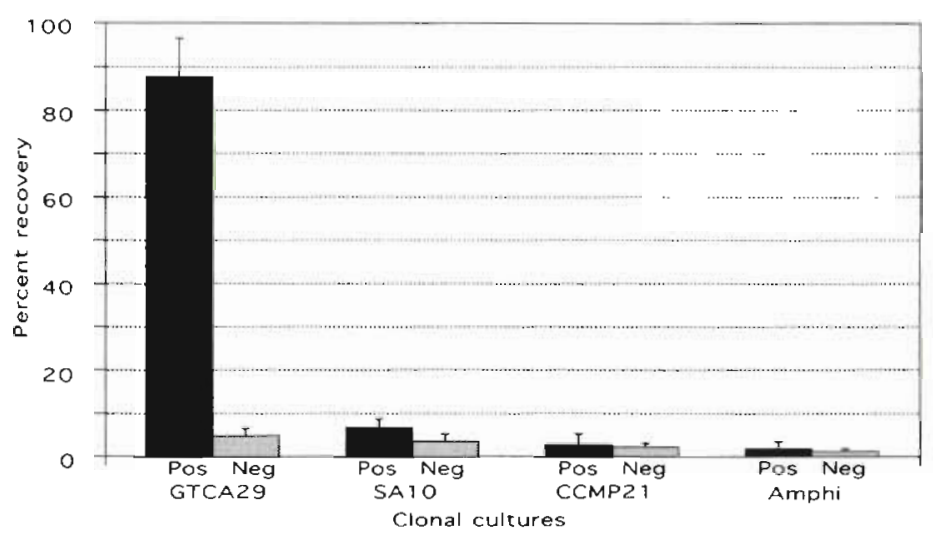

Fig. 6. Percentage of Alexandrium fundyense cells recovered in a sample containing a mixed culture of dinoflagellates. GTCA29: A. fundyense; SA10: Scrippsiella trochoidea; CCMP21: Prorocentrum micans; AMPHI: Amphidinium sp. Separation was performed using M-280 streptavidin beads and the indirect technique, with blocking by $5 \%$ NGS. Pos: positive labeling with primary antibody present; Neg: negative controls with primary antibody omitted. Error bars represent +1 SD for each treatment

\section{Magnetic separation using mixed cultures and natural seawater samples}

The indirect method was applied using $\mathrm{M}$ 280 streptavidin beads and 5\% NGS as blocking agent to analyze the efficiency of the magnetic beads on mixed plankton assemblages. The first tests used mixed cultures containing $25 \%$ of each of 4 dinoflagellate species (Alexandrium fundyense, Scrippsiella trochoidea, Prorocentrum micans and Amphidinium sp.). Recovery of $A$. fundyense cells was $91 \%$ (Fig. 6), about the same as that achieved with a clonal culture at similar bead:target cell ratios (in this experiment, the ratio was increased to 2000:1 to account for the other cells that were present). Recovery of the non-target species present in the sample was always lower than $7 \%(6.7,2.8$, and $1.9 \%$ for $S$. trochoidea, $P$. to $8 \%$ with $5 \%$ NGS. With the direct technique, negative control recoveries were ca $10 \%$ with both blocking agents.

Fig. 5B shows the results when the M-280 SaM beads were used. With NGS blocking, the percent recovery was higher than with BSA, using both the direct and the indirect techniques ( 91 and $92 \%$, respectively). In both approaches, however, the negative controls were also high (68 and $51 \%$ for direct and indirect, respectively). The best results were obtained with $5 \%$ BSA blocking for both the direct and indirect techniques (recovery of 85 and $88 \%$, respectively), both having extremely low recovery percentages in the negative controls $(0.5$ and $0.9 \%$, respectively).

Results with the M-450 GaM beads were quite different (Fig. 5C). There was no statistical difference $(p>0.05)$ in the percentage of recovered cells between the direct and the indirect technique when $5 \%$ NGS was the blocking agent (55 and 60\%, respectively). In this case, negative controls were $27 \%$ for the direct and $20 \%$ for the indirect technique. When the $5 \%$ BSA blocking agent was used, recovery of cells in the negative controls decreased drastically to $7 \%$ for the direct and $0.9 \%$ for the indirect technique. The percent recovery in the positive samples was lower, however, than those obtained. with NGS blocking (41 and $48 \%$ for direct and indirect techniques, respectively). These values were not significantly different from each other $(p>0.05)$.
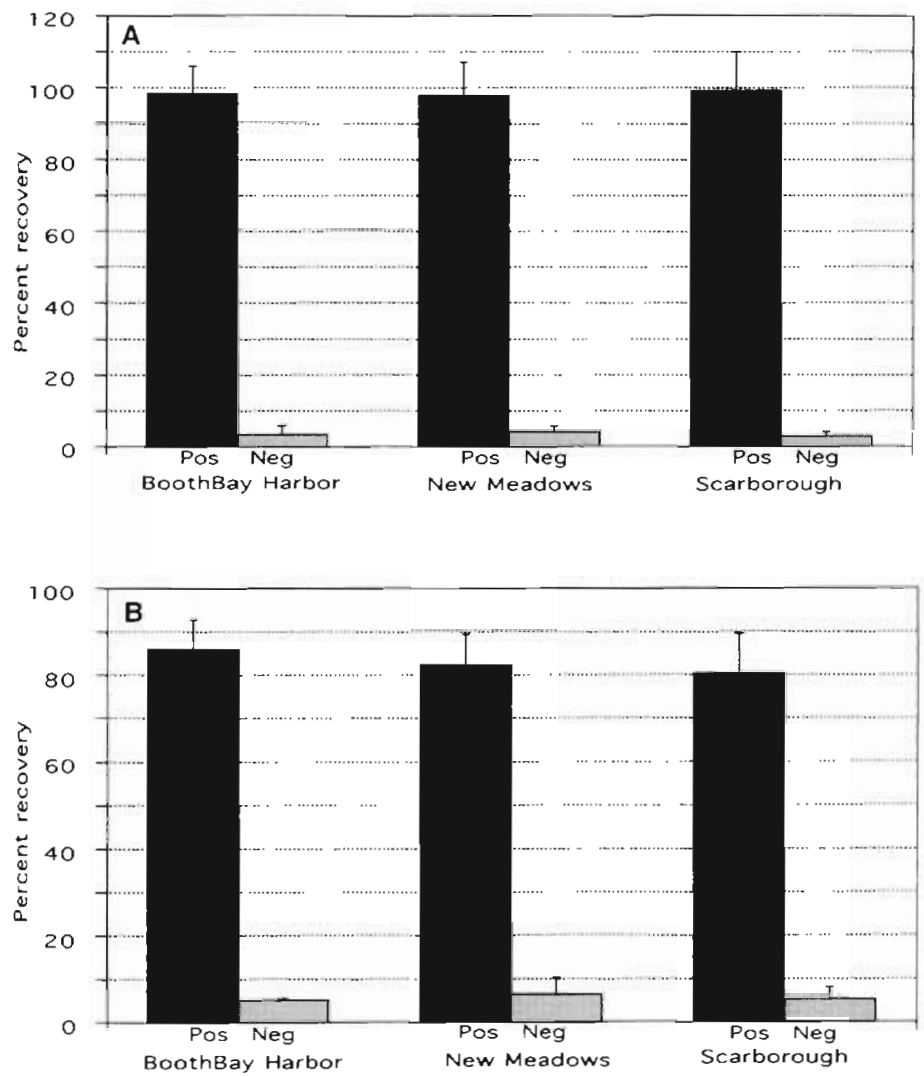

Fig. 7 Recovery percentages of cultured Alexandrium fundyense cells added to concentrated field samples containing naturally occurring Alexandrium spp. from 3 locations in the Gulf of Maine. (A) M280 streptavidin beads, indirect technique, and 5\% NGS for blocking; (B) M-280 SaM beads, direct technique, and BSA 5\% for blocking. Pos: positive labeling with primary antıbody present; Neg negative controls with primary antibody omitted. Error bars represent +1 SD for each treatment 

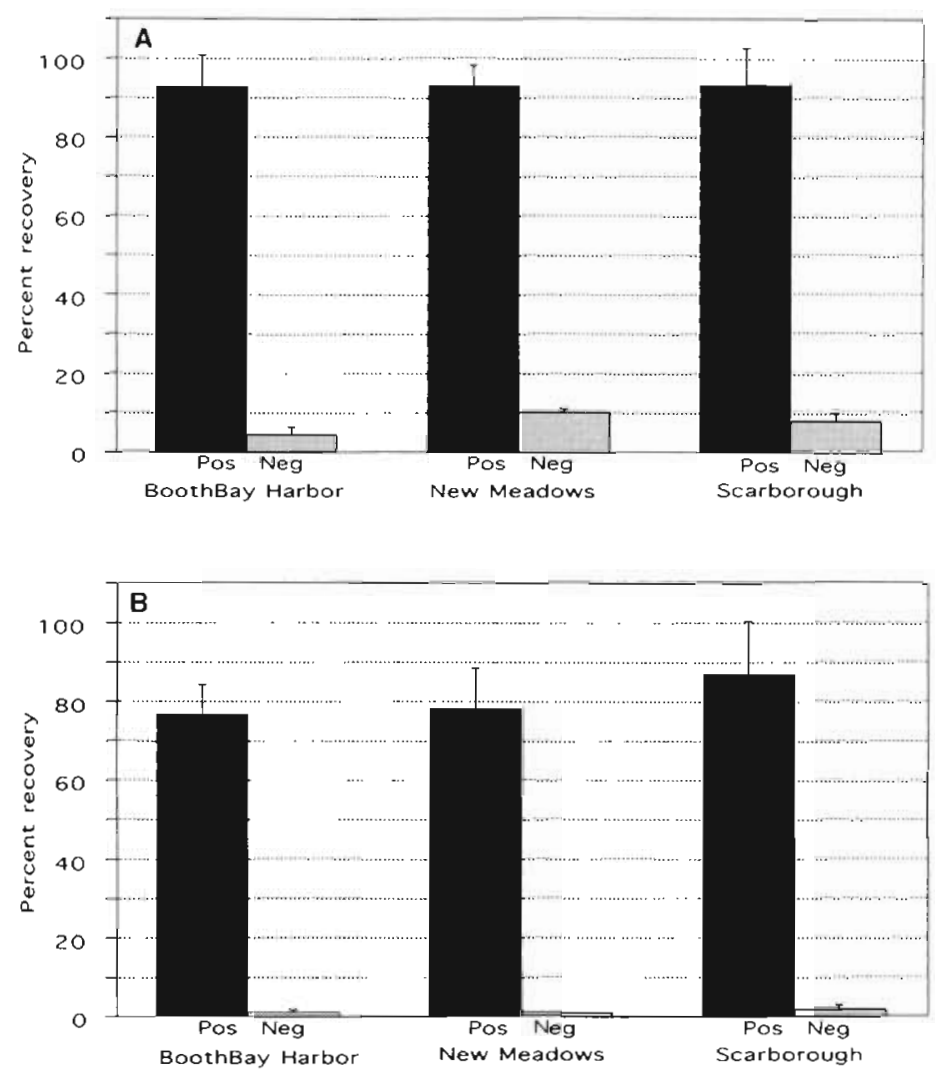

Fig. 8. Recovery percentages of naturally occurring Alexandrium spp cells from concentrated field samples from 3 locations in the Gulf of Maine. (A) M-280 streptavidin beads, indirect technique, and $5 \%$ NGS for blocking: (B) M-280 SaM beads, direct technique, and $5 \%$ BSA for blocking. Pos: positive labeling with primary antibody present; Neg: negative controls with primary antibody omitted. Error bars represent +1 SD for each treatment and the direct technique. Recovery percentages averaged $80 \%$ for the 3 samples (Fig. 7B), 10\% lower than with the streptavidin beads. Alexandrium spp. cells recovered in the negative controls were again less than $5 \%$ in all samples.

M-280 streptavidin-coated beads were then used to recover Alexandrium spp. cells from unspiked natural seawater samples at concentrations of 150,450 , and 700 cells $\mathrm{ml}^{-1}$ for Boothbay Harbor, New Meadows River, and Scarborough River, respectively (Fig. 8A). Using the indirect technique and 5\% NGS blocking, there were no statistical differences among the recovery percentages for Alexandrium spp. cells in the 3 field samples assayed $(p>0.05)$ and, in all cases, this percentage was ca $90 \%$. In the positive tests, only ca $6 \%$ of the total cells recovered were plankton cells other than Alexandrium spp. In the negative controls, recovery of Alexandrium spp. cells was ca $10 \%$, a value similar to those obtained for the clonal cultures, while $<1 \%$ of other phytoplanktonic cells were recovered.

With the M-280 SaM beads, 5\% BSA blocking and the direct technique, the results were also very promising (Fig. 8B). Approximately $80 \%$ of the Alexandrium spp. cells were recovered in each natural sample, while the Alexandrium spp. recovered in the negative controls remained very low at ca $1 \%$. In the positive tests, there was $<10 \%$ contamination by other phytoplankton cells. micans, and Amphidinium sp., respectively). The percent recovery in the negative controls was $5 \%$ or less.

All of the optimal conditions determined in the experiments with clonal cultures and artificial mixed samples were then applied to natural seawater samples. In the first experiments, sieved and concentrated natural samples from Boothbay Harbor, New Meadows River, and Scarborough River were enriched with Alexandrium fundyense cells from culture. Recovery was attempted using M-280 streptavidin beads, $5 \%$ NGS blocking, the indirect technique, and $6 \times 10^{6}$ beads per $500 \mu \mathrm{l}$ sample, giving a bead:target cell ratio of approximately 1200:1. The percent recovery of Alexandrium spp. in these samples were very similar to each other and to previous recoveries observed in culture, averaging 95\% (Fig. $7 \mathrm{~A}$ ). Alexandrium spp. cells recovered in negative controls were lower than $5 \%$ in all samples. M-280 SaM beads were also tested on the spiked natural seawater samples, using $5 \%$ BSA as a blocking agent

\section{DISCUSSION}

The use of magnetic beads for the isolation of target molecules or cells has increased rapidly over the last decade as monoclonal antibody and RNA or DNA probe technologies have emerged. A major breakthrough in applications of the immunomagnetic bead separation technique has been the analysis and sorting of haemopoietic stem cells from bone marrow, either for basic research or for clinical bone-marrow transplantation (Treleaven et al. 1984, Battye \& Shorthman 1991). The technique has also been used in the quantification of lymphocyte subsets in blood (Brinchmann et al. 1988), in the isolation of viruses and organelles (Uhlen 1989) and, in combination with the high binding affinity of streptavidin-biotin systems, in the rapid separation of DNA and RNA (Haukanes \& Kvam 1993). Magnetic beads are even employed in the fractionation of bovine spermatozoa for sex selection (Peter et al. 1993). 
Despite these numerous and diverse applications, this methodology, which not surprisingly has been principally driven by the medical and biotechnology fields, has not yet been exploited in environmental studies. It has been used somewhat successfully for the selective isolation of bacteria from lake water (only $20 \%$ recovery based on culturing of the isolates; Morgan et al. 1991), but never in the isolation of phytoplanktonic organisms such as dinoflagellates from the ocean, as reported here.

In this study, we developed an immunomagnetic bead method to isolate the toxic dinoflagellate Alexandrium fundyense from natural seawater samples containing an abundance of detritus and co-occurring micro-organisms. The recovery of target Alexandrium spp. cells varied with the bead size and coating, the blocking agent, and the ratio of beads:target cells. More than $90 \%$ of the labeled Alexandrium spp. cells in culture and in natural samples were isolated using the best experimental conditions tested to date, and in the experiments with natural samples the isolated Alexandrium spp. cells were $>90 \%$ pure. There were cell losses during initial antibody-labeling and processing before bead attachment, so $90 \%$ recovery refers to cells remaining after these procedures. The method is both simple and rapid, with a typical isolation requiring only a few steps and less than $4 \mathrm{~h}$ total time, including the incubation. This procedure holds great promise not only for the rapid isolation of Alexandrium spp. and other potentially harmful algae from field samples, but also for the isolation of numerous other planktonic species, including larval or life cycle stages. The autecologist is limited only by the availability of species-specific antibodies directed against cell surface antigens of the organism of interest, and these are becoming available at a rapid pace (reviewed by Shapiro et al. 1989, Anderson 1995).

Initial efforts to develop the method were focused on the basic parameters necessary for successful recovery of cultured Alexandrium fundyense cells, such as determining the optimal bead:target cell ratio, suitable incubation times, and optimal number of washing steps. Initial success using the indirect method and streptavidin-coated beads was followed by poor recovery when the direct method was attempted. It was then necessary to test other bead types with that technique and to change the blocking agent.

The first step was to determine the optimum number of beads per target cell. The bead manufacturer, Dynal, Inc., recommends a minimum 4:1 ratio of beads to target cells for positive selection and a minimum ratio of 10:1 for negative selection (see below for discussion of positive and negative selection), with a total bead concentration of at least 100 beads $\mathrm{ml}^{-1}$ of solution during the incubation period. Advanced Magnet- ics, Inc, another manufacturer of magnetic beads, recommends 20 to 80 beads per target cell for most applications, especially when the target cells are a small percentage of the total population. If target cell abundance is low, a low bead to target cell ratio results in a dilution of the bead particles by the total cell mass such that not enough beads reach their target. In natural seawater samples, where an unknown concentration of a target alga may span several orders of magnitude, it is necessary to ensure that an excess of beads is always added.

We determined the optimal bead:target cell ratio for streptavidin-coated beads using cultures of Alexandrium fundyense and found the best ratio to be 600:1 (Fig. 3). When the bead:cell ratio was lower, the recovery percentage was clearly reduced. Our data are thus in conflict with the manufacturer's recommendations, as well as with reports of ratios ca 75:1 for human cells (e.g. Kvalheim et al. 1987). There are several possible reasons for this large difference, including the specific antibody used, the density and accessibility of cell surface antigen sites, the type of beads used, and/or the characteristics of the target cells themselves.

The bead:target cell determinations were completed using an antibody supernatant concentration of 1:50 due to the limited availability of the species-specific primary antibody (M8751-1). This concentration is sufficient to yield good immunofluorescent labeling results, but may not saturate all the antigenic sites on the surface of Alexandrium fundyense. We found that increasing the primary antibody to full strength supernatant did not increase the percent recovery at lower bead:cell ratios. Thus, target cell characteristics may be more important than antibody concentration. Large, armored dinoflagellates are about 3 times as large as human erythrocytes and have rigid cellulose plates with intricate structure near the surface membrane. Alexandrium spp. cells may not attach as well to the beads and may require a greater number of beads on the surface of the cell for efficient isolation than has been reported for human erythrocytes. Whatever the reason, the data clearly show that at least 600 beads cell $^{-1}$ should be used for Alexandrium spp. In field samples with relatively few Alexandrium spp. present, a much higher ratio of 1000 or more beads cell ${ }^{-1}$ is recommended. Following our own recommendation, we used $6 \times 10^{6}$ beads $\mathrm{ml}^{-1}$ of concentrated field sample for each treatment. This would have been sufficient to isolate about 6000 Alexandrium spp. cells at a bead:cell ratio of 1000:1 This ratio should be empirically determined for other antibodies and cell types.

Another experimental parameter that is important for efficient isolations is the contact or incubation time between the target cells and the beads. Long incubation times (more than $1 \mathrm{~h}$ ) will increase the percentage 
of bound cells, but the additional time may also result in increased non-specific binding. One way to increase binding efficiency while preventing non-specific binding is to increase the bead concentration as the incubation time is shortened. Fig. 4 shows that a minimum of 15 min of incubation was necessary to guarantee suitable recovery of Alexandrium spp. cells when using the bead concentrations and ratios reported above, but shorter times still recovered 70 to $80 \%$ of the cells. Longer times did not significantly enhance recovery.

Minimizing the number of washing steps is an important aspect of reducing the total time for the procedure, but it also is critical with respect to the purity of the separated material. The bond between the beads and the target cells must be strong enough to withstand shear forces during repeated washing steps. In one experiment, the bead/cell complexes were washed between 1 and 8 times and the unbound Alexandrium spp. cells found in the supernatant of each wash were removed and counted. About $90 \%$ of the unbound cells were eliminated after 4 washes, with minimum loss of target cells. Each subsequent wash removed more unwanted, unbound cells, but about $1 \%$ of the attached target cells was also lost. Five washes are thus recommended, but fewer could be used if the objective was to maximize target cell recovery with less regard for the level of contamination. On the other hand, more washes could be used to obtain samples that are as pure as possible.

The size of the beads proved to be critical for the success of the technique. The M-450 goat anti-mouse beads $(4.5 \mu \mathrm{m}, \mathrm{Fig} .5 \mathrm{C})$ were inadequate for the isolation of Alexandrium spp. cells despite the fact that these beads are commonly recommended by Dynal, Inc. for human cell isolations and are the most frequently used in the quantification and elimination of mammalian cells (Kvalheim et al. 1987, Brinchmann et al. 1988, Vrendenburgh \& Ball 1990, Vredenburg et al. 1991). With these beads, less than $50 \%$ of the Alexandrium spp. cells were recovered compared to ca $90 \%$ with the M-280 sheep anti-mouse beads $(2.8 \mu \mathrm{m}$, Fig. 5B). This difference is probably not due to the different coatings on the beads (i.e. GaM vs SaM) since, in our experience, goat and sheep secondary antibodies are similar with respect to their affinity for primary antibodies. The difference more likely reflects the size of the beads. A reduction of the bead diameter from 4.5 to $2.8 \mu \mathrm{m}$ increases the surface area per unit mass from 1-4 $\mathrm{m}^{2} \mathrm{~g}^{-1}$ to 3-8 $\mathrm{m}^{2} \mathrm{~g}^{-1}$ (Dynal, Inc.). As a consequence, smaller beads can bind to a greater number of sites on the target cell, especially those antigenic sites that are recessed or inaccessible (e.g. the cingulum area; Fig. 1). More beads can attach per unit cell surface area, so the total number of beads per cell is higher. Furthermore, the smaller size of the beads per- mits gentler shear forces during magnetic isolation because smaller beads are attracted to the magnet slower than larger beads (Dynal, Inc.). Unfortunately, Dynal, Inc or other competing companies did not offer either SaM-coated beads in the larger size or GaM beads in the smaller size to allow us to fully explore the influence of bead size on Alexandrium spp. cell recoveries. Therefore, we recommend the smaller bead size for the gentle isolation of larger phytoplankton; but since we have not tested the isolation of phytoplankton cells other than Alexandrium spp. with different size beads, each investigator should empirically derive the proper bead size for each target species.

In addition to the size of the beads, the type of bead coating directly affected the recovery percentages. The highest recoveries (>90\%) were consistently obtained with the M-280 streptavidin-coated beads and the indirect technique (Figs. 5A, 7A, \& 8A). Recoveries were always slightly lower with the M-280 SaMcoated beads, using either the direct or indirect techniques and either BSA or NGS blocking (Fig. 5B), even when the incubation time between beads and cells in the SaM test was increased to $30 \mathrm{~min}$ (data not shown). The higher recovery of the treatments with streptavidin was also observed in field samples using the direct method and BSA blocking (Figs. 7B \& 8B). This result is consistent with the general characteristics of streptavidin-biotin reactions, which are typically exploited to amplify target signals through the high affinity of streptavidin for biotin and the availability of several binding sites on streptavidin for biotinylated antibodies (Wilchek \& Bayer 1988). However, cell recovery in the negative controls for the M-280 streptavidin-coated beads was also consistently double the levels achieved using SaM beads with BSA as blocking agent.

Two different blocking agents were tested. NGS was evaluated because it is used routinely for immunofluorescent tagging of Alexandrium spp. cells (Authors' unpubl. data) and other harmful algae (Bates et al. 1993), and BSA was tested because the beads are supplied in a BSA/PBS buffer to prevent clumping. The 2 blocking agents gave the same general recovery percentages for cells (Fig. 5A, B), but there were striking differences in the corresponding negative controls (i.e. with no primary antibody present, Fig. 5A, B). If the negative control recovery is high, isolated samples will be contaminated because of the binding of beads to unwanted cells and detritus. Therefore, achieving a low recovery in the negative control is extremely important. For streptavidin-coated beads, good recovery in the positive tests and low recovery in the negative controls were achieved using $5 \%$ NGS (Fig. 5A). BSA gave the same results as NGS in the direct technique, but non-specific binding was much higher 
$(>50 \%)$ when BSA was used to block with the indirect technique (Fig. 5A). Similarly, NGS was not a suitable blocking agent for the M-280 SaM beads, as recovery of unlabeled cells in the negative control was greater than $50 \%$ with both the direct and indirect techniques (Fig. 5B). BSA worked well with the SaM beads, as evidenced by the extremely low recoveries in the negative controls for both the direct and indirect techniques (Fig. 5B). Thus, the choice of blocking agent is dependent on the type of beads that are used for the isolations. Tween-20, which is commonly added along with NGS or BSA, may further reduce non-specific binding, but one must be careful that the detergent does not destroy surface membranes where the antigen of the target cells resides. We chose not to use Tween in our experiments.

Two main procedures were tested in the immunomagnetic separation of Alexandrium spp. cells: direct and indirect techniques (Fig. 2). The direct technique has the advantage of being fast and simple, since an initial incubation of a cell suspension with the primary antibody is not needed because the species-specific antibody has previously been linked directly to the beads. Direct binding of primary antibodies to magnetic beads can, however, result in poor isolation of the target cells (Haukanes \& Kvam 1993), presumably because the linkage between the antibody and the bead can hinder the antibody-antigen reaction. The indirect technique of isolation is often more efficient in this respect (Lea et al. 1990), and is also the method of choice when a cocktail of primary antibodies is used or when the target cells have a low surface antigen density (Haukanes \& Kvam 1993). In our experiments, the indirect and direct techniques were equally effective. Successful recoveries were more dependent on the bead type and blocking agent used.

In the case of the M-280 streptavidin-coated beads (Fig. 5A), the indirect technique showed significantly higher percentages of recovery than the direct technique ( 90 vs $50 \%$ ) using either NGS or BSA as a blocking agent, but the BSA blocking in the indirect treatment yielded high non-specific binding in the negative control. In contrast, when employing the M-280 SaM beads, both the direct and indirect techniques had similar recoveries of the target cells (ca $85 \%$ ) using either NGS or BSA, but in this case NGS yielded high nonspecific binding in the negative controls of both techniques. Therefore, the best results were obtained with (1) M-280 streptavidin-coated beads using the indirect technique and NGS for blocking (Fig. 5A); or (2) M-280 SaM beads with either the direct and indirect techniques and BSA for blocking (Fig. 5B). The negative controls with SaM-coated beads were exceptionally low $(2 \%)$ with BSA blocking. The variability in the recovery and negative control percentages with treat- ment type, bead coating, and blocking agent underscores the need to test all of these parameters empirically to arrive at the optimum protocols for a particular antibody and application.

The true test of the method is whether it is capable of separating target cells from natural samples containing many other organisms and detritus. Since methods to isolate live, cultured Alexandrium spp. cells have not yet been perfected, 3 different formalin-preserved field samples that contained Alexandrium spp. cells were tested, both with and without added Alexandrium fundyense cells from cultures. Results from both the spiked field samples (Fig. 7) and the unspiked field samples (Fig. 8) were the same as those reported for the cultured samples (Fig. 5). Using streptavidincoated beads, more than $90 \%$ of the Alexandrium spp. cells were recovered from both the spiked and unspiked preserved samples (Figs. $7 \mathrm{~A} \& 8 \mathrm{~A}$ ), with less than $10 \%$ recovery of unlabeled Alexandrium spp. in the negative controls. Using the SaM beads, 80 to $85 \%$ of the Alexandrium spp. cells present were recovered, with less than $10 \%$ recovery in the negative controls (Figs. 7B \& 8B). Generally, the purified subsets were 90 to $95 \%$ Alexandrium spp., while co-occurring organisms composed approximately $5 \%$ of the total captured cell population. Therefore, either the direct or the indirect approaches are capable of purifying Alexandrium spp. from field populations.

If high recovery percentages are desired, the streptavidin-coated beads are recommended, but these beads can only be used with the indirect protocol. Each field sample must thus first be incubated with the primary antibody and then with a biotinylated secondary before the beads are added. SaM beads can be used with either the direct or indirect method, but recovery percentages are slightly lower than with streptavidincoated beads. The direct technique seems more appropriate for field samples, as the SaM beads can be pre-incubated in large quantities with the primary antibody to 'activate' the beads, and isolation of target cells would be reduced to only a few simple steps washing the preservative from the sample, incubating with the 'activated' beads, and collecting the purified. subsample using a magnet and several additiona] washes.

\section{Applications}

\section{Separation}

One of the major motivations for the development of this method is the need to obtain measurements of key physiological parameters (e.g. C:N:P ratios, chlorophyll content, nutrient uptake rates) for a single spe- 
cies in a mixed plankton community. Manual singlecell isolations (Rivkin \& Seliger 1981) are laborious and therefore can only be applied to analyses when a relatively small number of cells are required. Species-specific primary production and photosynthetic activity (Rivkin 1985) of several oceanic dinoflagellates have been studied in this way. Alternatively, sorting the population of interest using flow cytometry based on the autofluorescence signal of phytoplankton pigments and the subsequent measurement of internal carbon and nitrogen pools has recently been accomplished for oceanic prochlorophytes (Olson et al. 1990) which have unique size and pigment characteristics. Thus far, however, flow cytometric sorting of immuno-labeled cells in natural samples has not been demonstrated because of difficulties in labeling cells with fluorochromes that are spectrally distinct and sufficiently bright to distinguish target cells from co-occurring, autofluorescent organisms. Furthermore, it is often necessary to highly concentrate field samples to obtain a sufficient number of Alexandrium spp. cells through flow cytometric sorting. Clogging of the flow cytometer's aperture becomes a major problem for concentrated field samples. If the sample is diluted to prevent clogging, then the time to sort a sufficient number of target cells from a sample becomes prohibitive. With magnetic bead separations, neither background autofluorescence nor flow cell problems are an issue. The cost of flow cytometric sorting is also much higher when one considers the skilled labor and maintenance costs necessary to operate one of these finely-tuned optical instruments. In contrast, the appropriate beads and magnet are inexpensive (approximately US\$2 per sample), unbreakable, and can be easily transported to the field for rapid separations. However, assuming that the technical and monetary problems of flow cytometric sorting were overcome, flow cytometry may be capable of yielding a higher degree of purity and viability than was accomplished here using beads.

All separation attempts thus far have been 'positive selection'. This means that the target bead/cell complex is separated for later analysis. It is also possible to use immunomagnetic separation for 'negative selection', in which the cells attached to the beads are removed and discarded and the remainder of the sample is analyzed (Battye \& Shortmann 1991, Haukanes \& Kvan 1993). One can envision situations in which both approaches might be useful in ecological investigations.

Thus far, our efforts have been focused on isolating bead/cell complexes from preserved samples, but work remains to be done to show that the separated fraction is then useful for measurements of physiological parameters. In some instances, the applications should require no modifications of the method described here. For example, a plankton sample could be incubated with ${ }^{14} \mathrm{C}$ in a normal productivity protocol, after which the immunomagnetic separation procedure could be used to remove cells of a target species for subsequent scintillation counting. The attached beads should not interfere with the counting procedure, although this remains to be demonstrated. Other applications are potentially more problematic, however, and will require that the beads be detached from the cell prior to analysis. Attached beads could be a concern in analyses of species-specific trace metal quotas, for example, or in $\mathrm{C}: \mathrm{N}$ measurements. Work is underway to ascertain the level of potential contamination from not only the beads but also from the preservatives used for various analytical procedures, as well as to devise ways to detach beads from the cells with minimum disruption of cell integrity and cellular metabolites.

Many physiological measurements may require isolation of cells from 'live' samples, where either no preservative can be tolerated before the subsequent measurement or the cells must retain their viability after the bead treatment. Unfortunately, our preliminary efforts to separate live cells using beads have been unfavorable. One reason the recoveries were low may be due to a high percentage of the live cells losing their theca during the protocol, radically decreasing the percentage of whole cell recovery. Furthermore, we note that binding of the primary antibody to live cells (using an FITC-secondary antibody for detection) produced a weaker signal with live cells than with preserved ones (data not shown), suggesting that the antigenic sites on live cells may not be as accessible to bead attachment. These problems might be avoided by reducing the number of wash steps, especially with the 'indirect' method or by using gentle filtration instead of centrifugation for the washes. Increasing both the primary antibody concentration or the incubation times between the cells/antibody or cells/beads may also facilitate bead attachment to live cells. If further modifications to the present protocol prove successful, the use of magnetic beads could become a promising methodology for the recovery of live cells as well, especially for cells that may not be as sensitive to manipulation as dinoflagellates.

\section{Enumeration}

In the coastal waters of the Gulf of Maine, Alexandrium spp. generally occurs in concentrations ranging from undetectable to approximately $10^{4} \mathrm{l}^{-1}$ Usually, however, the concentration is relatively low and even several hundred cells per liter can still cause shellfish toxicity. To enumerate Alexandrium spp. during all 
stages of a bloom, it is often necessary to concentrate the phytoplankton onto $20 \mu \mathrm{m}$ sieves following collection. This concentration step, while necessary for early detection, has the undesirable effect of concentrating other similarly sized co-occurring organisms and detritus. This makes standard microscope counting very difficult, especially when there are only a few Alexandrium spp. cells in the samples. Immunofluorescent labeling techniques have recently been developed to assist in species identification in this regard. (e.g. Anderson 1995). Immunomagnetic bead technology has the potential to further facilitate this process by rapidly isolating the relatively low abundance target species in a short time, so that only a small 'clean' sample is examined under a microscope for counting. However, it is of note that the recovery percentage reported here represents the fraction of the total Alexandrium spp. population recovered with the magnet after antibody labeling. It is not the fraction of the total Alexandrium spp. cells present in the sample before any processing, as cells were undoubtedly lost during the labeling and washing steps. Our experience has been that 30 to $50 \%$ of the cells in a sample can be lost during immunofluorescent processing (Anderson 1995). The immunomagnetic separation method described here is thus not yet at the stage where it can be recommended for quantitative estimates of the abundance of a target species in a sample. Rather, it is useful in obtaining relatively pure suspensions of cells of 1 species from a mixed assemblage. Work is ongoing to modify the processing steps so that cell loss is minimized, in hopes that this method can become a tool for enumeration of a target species. The direct technique seems especially promising in this respect.

As an alternative to microscopic counting, rapid detection and semi-quantitative analysis of Alexandrium spp. may be accomplished by modified ELISA techniques on the intact cells. However, these methods suffer from the same problems as microscopic counting - namely, that there are many other organisms and detrital particles present in the sample which may interfere with the assay. These problems, termed 'matrix effects', can create high background levels and high detection limits. The use of magnetic beads to rapidly purify target cells from the sample before the assay could be one way to eliminate 'matrix effects' for the development of ELISA-based assays of natural seawater samples.

\section{Summary}

Here we presented the details of a procedure which holds great promise for the phytoplankton autecologist. Immunomagnetic separation of the cells of a sin- gle species from natural water samples is clearly feasible once a suitable cell surface antibody is available for that species. The method is rapid, simple, and quite effective in eliminating contaminants and interferences. Further refinement is still needed, but the basic procedures are defined. The next major challenge is to apply this procedure to natural samples, especially live samples, to obtain the species-specific physiological measurements that are so critical to our understanding of the bloom dynamics of individual organisms.

Acknowledgements. We thank Y. Ishida and Y. Sako for generously providing antibody M-8751-1, and C. Aguilera for the graphic work. This research was supported by National Science Foundation grants OCE-8911226 and OCE-9415536 (to D.M.A.) and by the National Sea Grant College Program Office, Department of Commerce Grant No. NA46-RG-0470 (WHOI Sea Grant Projects R/B-130; to D.M.A.), and by Spanish Ministerio de Educacion y Ciencia fellowships AP94517384765 and PF947224875 (to A.A. and S.G.G.). Contribution No. 9275 from the Woods Hole Oceanographic Institution.

\section{LITERATURE CITED}

Adachi M, Sako Y, Ishida Y (1993a) The identification of conspecific dinoflagellates Alexandrium tamarense from Japan and Thailand by monoclonal antibodies. Nippon Siusan Gakkaishi 59(2):327-332

Adachi M, Sako Y. Ishida Y (1993b) Application of monoclonal antibodies to field samples of Alexandrium species. Nippon Suisan Gakkaishi 59:1171-1175

Anderson DM (1995) Identification of harmful algal species using molecular probes: an emerging perspective. In: Lassus P, Arzul G, Erard-Le Denn EE, Gentien P, MarcaillouLeBaut $C$ (eds) Harmful marine algal blooms. Lavoisier Sci Publ, Paris, p 3-13

Anderson DM, Kulis DM, Cosper EM (1989) Immunofluorescent detection of the brown tide organism Aureococcus anophagefferens. In: Cosper EM, Carpenter EJ, Bricelj VM (eds) Novel phytoplankton blooms: causes and impacts of recurrent brown tides and other unusual blooms. Springer-Verlag, New York, p 213-228

Bates SS, Leger C, Keafer BA, Anderson DM (1993) Discrimination between domoic-acid-producing and nontoxic forms of the diatom Pseudonitzschia pungens using immunofluorescence. Mar Ecol Prog Ser 100:185-195

Battye FL, Shorthman K (1991) Flow cytometry and cell-separation procedures. Curr Biol 3:238-241

Brinchmann JE, Vartda] F, Gaudernack G, Markussen G, Funderud S. Ugelstad J, Thorsby E (1988) Direct immunomagnetic quantification of lymphocyte subsets in blood. Clin Exp Immunol 71:182-186

Campbell L, Carpenter EJ (1987) Characterization of phycoerythrin-containing Synechococcus spp. by immunofluorescence. J Plankton Res 9:1167-1181

Campbell L, Carpenter EJ, Iacono VI (1983) Identification and enumeration of marine chroococcuid cyanobacterla by immunofluorescence. Appl Environ Microbiol 46:553-559

Costas E, Gonzalez de Chavarri E, Aguilera A, Gonzalez-Gil S, Lopez-Rodas V (1993) Use of lectins to characterize and differentiate unicellular algae. Bot Mar 36:1-4

Franks PJS, Anderson DM (1992) Alongshore transport of a 
toxic phytoplankton bloom in a buoyancy current: Alexandrium tamarense in the Gulf of Maine. Mar Biol 112: $153-164$

Guillard RRL, Ryther JH (1962) Studies of marine planktonic diatoms. I. Cyclotella nana Hustedt, and Detonula confervacea (Cleve) Gran. Can J Microbiol 8:229-239

Hanau D. Smith DA (1988) A method for the rapid isolation of human epidermal Langerhans cells using immunomagnetic microspheres. J Invest Dermatol 91:274-280

Haukanes B, Kvam C (1993) Application of magnetrc beads in bioassays. Biotechnology 11:60-63

Hiroishi S, Uchida A, Nagasaki K, Ishida Y (1988) A new method for identification of inter- and intra-species of the red tide algae Chattonella antiqua and Chattonella marina (Raphidophyceae) by means of monoclonal antibodies. J Phycol 24:442-444

Kvalheim G, Fodstad O, Pihl A, Nustad K, Pharo A, Ugelstad $J$, Funderud S (1987) Elimination of B-lymphoma cells from human bone marrow: a model experiment using monodispersed magnetic particles coated with primary monoclonal antibodies. Cancer Res 47:846-851

Lea T, O'Connell JP, Nustad K, Funderud S, Berge A, Rembaum A (1990) Microspheres as immunoreagents for cell identification and cell fractionation. In: Helameds MR, Lindmo T, Mendelsohn $M$ (eds) Flow cytometry and sorting Wiley-Liss Inc, New York, p 367-380

Li WKW (1995) Composition of ultraphytoplankton in the central North Atlantic. Mar Ecol Prog Ser 122:1-8

Lund A, Hellemnn AL, Vartdal F (1988) Rapid isolation of K88 E. coli by using immunomagnetic particles. J Clin Microbiol 26:2572-2575

Morgan JAW, Winstanley C, Pickup RW, Saunders JR (1991) Rapid immunocapture of Pseudomonas putida cells from lake water by using bacterial flagella. Appl Environ Microbiol 57:503-509

Nagasaki K, Uchida A, Hiroishi S, Ishida Y (1989) Identification of red tide algae Chlorella marina and Chattonella antiqua by means of monoclonal antibodies. In: Miyachi S, Karube I, Ishida Y (eds) Current topics in marine biotechnology. Fuji Technol Press, Tokyo, p 161-164

Olson RJ, Chisholm SW, Zettler ER, Altabet MA, Dusenberry JA (1990) Spatial and temporal distributions of prochlorophyte picoplankton in the North Atlantic Ocean. Deep Sea Res 37:1033-1051

Peter AT, Jones PP, Robinson JP (1993) Fractionation of bovine spermatozoa for sex selection: a rapid immunomagnetic technique to remove spermatozoa that contain the H-Y antigen. Theriogenology 40:1177-1185

Rivkin RB (1985) Carbon-14 labeling patterns of individual marine phytoplankton from natural populations. Mar Biol 89:135-142

Rivkin RB, Seliger HH (1981) Liquid scintillation counting for ${ }^{14} \mathrm{C}$ uptake of single algal cells isolated from natural sam-

This article was presented by D. A. Caron (Senior Editorial Advisor), Woods Hole, Massachusetts, USA ples. Limnol Oceanogr 26:780-784

Sako Y, Adachi M, Ishida Y (1993) Preparation and characterization of monoclonal antibodies to Alexandrium species In: Smayda TJ, Shimizu Y (eds) Toxic phytoplankton blooms in the sea. Elsevier Sci Publ, New York, p 87-93

Scholin CA, Villac MC, Buck. KR, Krupp JM, Powers DA, Fryxell GA, Chavez FP (1994) Ribosomal DNA sequences discriminate among toxic and non-toxic Pseudonitzschia species. Nat Toxins 2:152-165

Shapiro LP, Campbell L, Haugen EM (1989) Immunochemical recognition of phytoplankton species. Mar Ecol Prog Ser $57: 219-224$

Sharon N, Lis H (1989) Lectins as recognition molecules. Science 246:227-234

Treleaven JG, Ugelstad J, Phillip T, Gibson FM, Rembaum A Caine GD (1984) Removal of neuroblastoma cells from bone marrow with monoclonal antibodies conjugated to magnetic microspheres. Lancet 1:70-84

Uhlen M (1989) Magnetic separation of DNA. Nature 340 $733-734$

Vartdal F, Kvalheim G, Lea TE, Bosnes V, Gaudernack G, Ugelstad J, Albrechsten D (1987) Depletion of T lymphocytes from human bone marrow. Transplantation 43: 366-369

Vrendenburg JJ, Ball ED (1990) Elimination of small cell carcinoma of the lung from human bone narrow by monoclonal antibodies and immunomagnetic beads. Cancer Res 50:7216-7220

Vrenderburg JJ, Simpson W, Memoli VA, Ball ED (1991) Reactivity of anti-CD15 monoclonal antibody PM-81 with breast cancer and elimination of breast cancer cells from human bone marrow by PM- 81 and immunomagnetic beads. Cancer Res 51:2451-2455

Vrieling EG, Gieskes WWC, Rademaker TWM, Vriezekolk G. Peperzak L, Veenhuis M (1995) Flow cytometric identification of the ichthyotoxic dinoflagellate Gyrodinium aureolum in the central North Sea. In: Lassus P, Arzul G, ErardLe Denn EE, Gentien P, Marcaillou-LeBaut C leds Harmful marine algal blooms. Lavoisier Sci Publ, Paris, $\mathrm{p}$ $743-751$

Vrieling EG, Peperzak L, Gieskes WWC, Veenhuis M (1994) Detection of the ichthyotoxic dinoflagellate Gyrodinium (cf.) aureolum and morphologically related Gymnodinium species using monoclonal antibodies: a specific immunological tool. Mar Ecol Prog Ser 103:165-174

Wilchek M, Bayer E (1988) The Avidin-Biotin complex in bioanalytical applications. Analyt Biochem 171:1-32

Wynick D, Bloom R (1990) Magnetic bead separation of anterior pituitary cells. Neuroendocrinology 52:560-565

Yasumoto T, Oshima $Y$, Sugawara W, Fukuyo Y, Oguri H, Igarashi T, Fujita N (1980) Identification of Dinophysis fortii as the causative organism of diarrhetic shellfish poisoning. Bull Jap Soc Sci Fish 46:1405-1411

Manuscript first received: December 6, 1995

Revised version accepted: August 9, 1996 